\title{
New Media and Political Dissent in Egypt
}

\section{Medios nuevos de comunicación y disidencia política en Egipto}

\author{
Charles Hirschkind \\ Department of Anthropology \\ University of California, Berkeley
}

\section{SUMMARY}

This paper explores some of the ways that the Internet, and particularly the practice of blogging, has opened up new political possibilities in Egypt. As I examine, political bloggers in this country (Islamist as well as secularist) have pioneered new language forms and video styles in order to articulate an arena of political life they refer to as "the street." Egyptian bloggers render visible and publicly speakable practices of state violence that other media outlets cannot easily disclose. In discussing the sensory epistemology informing these blogging practices, I give particular attention to the way traditions concerning the sonority of the Arabic language and the relation of written to spoken forms are exploited and reworked by some of Egypt's most prominent political bloggers. I also examine how these language practices find a visual and aural analogy in the grainy cellphone video recordings found on many of Egypt's political blogs. This paper analyzes such practices in relation to emergent forms of political agency and contestation in contemporary Egypt.

Key Words: Egypt, Blogsphere, Political Dissent, Islamists, Secularists, Sensory Politics.

\section{RESUMEN}

El autor explora algunos de los modos como Internet, en particular el escribir y publicar en un blog, ha abierto nuevas posibilidades políticas en Egipto. El estudio revela que los blogueros políticos en este país (que incluye tanto a islamistas como a laicistas) han creado nuevas formas de lenguaje y nuevos estilos de vídeo con los que vertebrar un espacio de vida política al que se refieren como "la calle". Los blogueros egipcios hacen visibles y motivo de debate público acciones violentas del Estado que otros medios informativos no pueden divulgar con la misma facilidad. El autor se detiene especialmente en el modo como los blogueros políticos más sobresalientes del país recurren y adaptan las tradiciones relativas a la sonoridad de la lengua árabe y a la conexión que existe en ella entre las formas habladas y las escritas. Asimismo, examina el modo como estas prácticas lingüísticas guardan una similitud visual y oral con las grabaciones de vídeo, de baja resolución, que se hacen con teléfonos móviles y que aparecen des- 
pués en los blogs políticos. Todas estas nuevas prácticas revelan formas emergentes de acción política y de disidencia en el Egipto actual.

Palabras clave: Egipto, Blogsfera, Disidencia política, Islamistas, Laicistas, Política de las sensaciones.

\section{INTRODUCTION}

On April $6^{\text {th }}$, 2008, a general strike took place in Egypt, an event which saw vast numbers of workers and students stay home from their sites of work or school. The strike, the largest anti-government mobilization to occur in Egypt in many years, had been initiated by labor activists in support of striking workers at the Mahalla textile factory who had for months been holding out for better salaries and improved work conditions. In the month leading up to the strike, however, the aim of the action enlarged beyond the scope of the specific concerns of the factory workers. Propelled by the efforts of a group of activists on Facebook and within the Egyptian blogosphere, the strike shifted to become a national day of protest against the corruption of the Mubarak regime, and particularly against the regime's complete inaction in the face of steadily declining wages and rising prices. Most stunning about the event, and most worrisome to the Egyptian state, was the way the idea of a general strike had been generated: Esra' 'Abd al-Fattah, a young woman with little experience as an activist who lived just outside of Cairo, had initiated a group on Facebook calling for a sympathy strike with the textile workers. Within two weeks, close to 70,000 Facebook members had signed on. Political bloggers also began to promote the strike, and by the time the $1^{\text {st }}$ of April came around most of the political opposition parties had been brought on board and were vigorously trying to mobilize their constituencies. When the $6^{\text {th }}$ arrived, Egypt witnessed its most dramatic political mobilization in decades, an event that brought together people across the political spectrum, from Muslim Brotherhood members to Revolutionary Socialists.

In this paper I want to address some of the ways the practice of blogs is changing the conditions of political discourse and action within Egypt today, one example of which was seen in the mobilization on April $6^{\text {th }}{ }^{1}$ What is most striking about the Egyptian blogosphere, as I will argue, is the extent to which blogs are contributing to the elaboration of a political discourse that cuts across the institutional barriers that have until recently polarized

\footnotetext{
${ }^{1}$ In this paper, I address one small corner of the Egyptian blogosphere defined around a shared emphasis on contemporary national political concerns. The majority of Egyptian blogs are not explicitly political but focus on any number of themes, from movie and music stars, to poetry, to fashion, to calls for greater piety.
} 
Egypt's political terrain, between more Islamicly-oriented currents (most prominent among them, the Muslim Brotherhood) and secular-liberal ones. Since the rise of the Islamist Revival in the 1970s, Egypt's political opposition has remained sharply divided around contrasting visions of the proper place of religious authority within the country's social and political future, with one side viewing secularization as the eminent danger, and the other emphasizing the threat of politicized religion to personal freedoms and democratic rights ${ }^{2}$. This polarity has tended to result in a defensive political rhetoric and a corresponding amplification of political antagonisms, a dynamic the Mubarak regime has repeatedly encouraged and exploited over the last 30 years in order to ensure a weak opposition. What is striking about the blogosphere I examine here is the extent to which it has engendered a political language free from the problematic of secularization vs. fundamentalism that governs so much of political discourse in the Middle East and elsewhere. The practices of reporting, critique, argument, not to mention satire and humor, that are shaping the corner of the Egyptian blogosphere I am concerned with resist categorization in terms of the binary of religion and secular - terms that have so forcefully shaped modern political life- but are geared to creating an arena of discursive engagement which transcends the institutional forms within which these categories are so thoroughly rooted today in Egypt. Thus, while many of those who write and comment within the blogosphere are involved in Islamist organizations, and identify themselves on their blogs as members of these organizations, the political language they are developing online departs radically from that used within these organizations.

The public arena of activist blogging I describe responds first and foremost to the question of, how can effective political agency be established today in the face of the predations and repressive actions of the Egyptian state? And, concomitantly, what forms of political critique and interaction can mediate and encompass the heterogeneity of religious and social commitments that constitute Egypt's contemporary political terrain? While the political blogosphere has certainly been enabled by a politics of tactical alliance among participants of differing political orientation, the form of discursive interaction that has emerged from this tactical engagement are producing unique practices of public reason and dialogue. As I argue, while these political practices — styles of reflection, argumentation, and critical engagement - are not specifically Islamic, they are deeply indebted to recent and ongoing transformations of Islamic forms of authority and knowledge in

\footnotetext{
${ }^{2}$ For useful discussions of Egyptian political life and the role of Islamic movements see Abdo (2000), Beinin and Stork (1997), Baker (2003).
} 
Egypt $^{3}$. In my analysis I give particular attention to what I shall call the fuzzy realism through which exceptional and daily acts of violence are objectified within the Egyptian blogosphere, as the experience of a collective national subject.

Before going further, however, I just want to acknowledge that, given how recent this domain of web-based activity is, and how rapidly it is changing, it is really impossible to speak with any certainty about its political significance, or the impact it will have on Egypt's future. Nor is there any warrant for making strong claims about its political potential: since the April $6^{\text {th }}$ strike, the government has effectively clamped down on public protests, making a repeat of that event extremely difficult to imagine, at least in the short term (Faris 2009). Thus, I have less to say here about the direct impact of blogging on Egypt's reigning political order than about the practices of critique, argument, and commentary that now define the arena of blog-based political discourse, and about how within this quite restricted domain, an important experiment in political thought and action is taking place across the Islamist/secular divide, one well worth our attention.

\section{EMERGENCE OF THE BLOGOSPHERE}

The blogosphere that burst into existence in Egypt around 2004 and 2005 in many ways provided a new context for a process that had begun somewhat earlier, in the late 1990s: namely, the development of practices of coordination and support between secular leftist organizations and associations, and Islamist ones (particularly the Muslim Brotherhood) - a phenomenon almost completely absent in the prior decades. Toward the end of the decade of the 90s, Islamist and leftist lawyers began to agree to work together on cases regarding state torture, whereas in previous years, lawyers of one affiliation would almost never publicly defend plaintiffs from the other. This period also saw various attempts by Islamist thinkers to found political parties (most famously, the Center Party, Hizb al-Wasat) on a platform capable of attracting members well outside the Muslim Brotherhood and other Islamist formations, including Christians ${ }^{4}$. Overall, however, such attempts have had little success, owning to the Egyptian state's refusal to grant legal authority to these parties.

3 On the reconfiguration of Islamic authority in Egypt, and in the Middle East more generally, see Agrama (2010), Hirschkind (2006), Mahmood (2005), Salvatore (1997), Skovgaard-Petersen (1997).

${ }^{4}$ On the emergence and career of Hizb al-Wasat, see Norton (2005), Stacher (2002), Wickham (2004). 
The most successful experiment at reaching across Egypt's political spectrum came in 2004 with the emergence of what is called the Kifaya movement, a political formation that brought together Islamists, Muslim Brothers, communists, liberals, and secular-leftists, joined on the basis of a common demand for an end to the Mubarak regime and a rejection of the Gamal Mubarak's succession of his father as president ${ }^{5}$. Kifaya was instrumental in organizing a series of demonstrations between 2004 and 2007 that for the first time explicitly called for the president of Egypt to step down, an unheard of demand prior to that moment insomuch as any direct criticism of the president or his family had until then always been taboo, and met by harsh reprisals from the state. Kifaya not only succeeded in bringing huge numbers of people of different political persuasions into the street to protest government policies and actions, they were also the first political movement in Egypt to exploit the organizing potential of the Internet, founding a number of blog sites from which to coordinate and mobilize demonstrations and strikes. When Kifaya held its first demonstrations, at the end of 2004, a handful of bloggers both participated and wrote about the events on their blogs. Within a year the number of blogs had jumped to the hundreds. Today there are thousands of blogs, many tied to activism, street politics, solidarity campaigns, and grassroots organizing ${ }^{6}$.

Two key events highlighted the political potential of blogging in Egypt and helped secure the practice's new and expanding role within Egyptian political life. It had long been known that the Egyptian state routinely abused and tortured prisoners or detainees (hence the US's choice of Egypt in so called "rendition" cases). For its part, the state has always denied that abuse took place, and lacking the sort of evidence needed to prosecute a legal case, human rights lawyers and the opposition press had never been able to effectively challenge the state's official position. This changed when a blogger named Wael Abbas, whose blog is titled al-wa'i al-masri ("Egyptian Awareness"), placed on his blog site a cell-phone recorded video he had been sent by another blogger that showed a man being physically and sexually abused by police officers at a police station in Cairo. (Apparently, the clip had been filmed by officers with the intention of intimidating the detainee's fellow workers.)

Once this video clip was placed on YouTube and spread around the Egyptian blogosphere, opposition newspapers took up the story, citing the

\footnotetext{
5 The co-evolution of the Kifaya movement and Egypt's political blogosphere has been examined by Radsch (2008).

${ }^{6}$ The by-far most useful analysis on the Egyptian blogosphere can be found in two articles by Marc Lynch (2007a, 2007b). For a more general treatment of Internet use and the growth of blogging in the Middle East, see Bunt (2009: 131-176).
} 
blogs as their source. When the victim was identified and encouraged to come forth, a human rights agency raised a case on his behalf against the officers involved that eventually resulted in their conviction, an unprecedented event in Egypt's modern history. Throughout the entire year that the case was being prosecuted, bloggers tracked every detail of the police and judiciary's handling of the case, their relentless scrutiny of state actions frequently finding its way into the opposition newspapers. Satellite TV talk shows followed suit, inviting bloggers on screen to debate state officials concerned with the case. Moreover, within a month of posting the torture videos on his web site, Abbas and other bloggers started receiving scores of similar cell-phone films of state violence and abuse taken in police stations or during demonstrations.

This new relation between bloggers and other media forms has now become standard: not only do many of the opposition newspapers rely on bloggers for their stories; news stories that journalists can't print themselves without facing state persecution -for example, on issues relating to the question of Mubarak's successor - are first fed to bloggers by investigative reporters; once they are reported online, journalists then proceed to publish the stories in newsprint, citing the blogs as source, this way avoiding the accusation that they themselves invented the story. Moreover, many young people have taken up the practice of using cell-phone cameras in the street, and bloggers are constantly receiving phone film-footage from anonymous sources that they then put on their blogs.

A second event that brought bloggers to national attention also concerned police abuse: during a Kifaya demonstration in May 2005, thousands of riot police and paid thugs attacked a small group of about a hundred protesters, including many women who were beaten and harassed by the attackers. A number of bloggers were present at the event, and immediately posted cell phone videos and extensive descriptions of the attack on their sites. These accounts then made their way first to Egypt's opposition press, then to the international press -including al-Jazeera - and finally to the courts. This and subsequent blog exposés on sexual harassment in Egypt raised to national public attention an issue that until then had rarely received acknowledgment in any of the popular media. Indeed, at the end of 2008 a court judge sentenced two men to three years in prison on a sexual harassment charge, an outcome that was unimaginable until the blogosphere forced the issue into the realm of public debate.

These events played a key role in shaping the place that the blogosphere would come to occupy within Egypt's media sphere. Namely, bloggers understand their role as that of providing a direct link to what they call "the street," conceived primarily as a space of state repression and political violence, but 
also as one of political action and popular resistance. They render visible and publicly speakable a political practice-the violent subjugation of the Egyptian people by its authoritarian regime-that other media outlets cannot easily disclose, due to censorship, practices of harassment, and arrest. This includes not only acts of police brutality and torture, but also the more mundane and routine forms of violence that shape the texture of everyday life. For example, blogs frequently include reporting on routine injustices experienced in public transportation, the cruel indifference of corrupt state bureaucrats, sexual harassment encountered in the streets, as well as the many faces of pain produced by conditions of intense poverty, environmental toxicity, infrastructural neglect, and so on. Additionally, the focus on torture and police violence among bloggers must be understood not only as a moral rejection of such practices. The images of state violence circulated on blogs provide a visual anchor for a much broader sense of discontent with the authoritarian, neo-liberal regime, with the poverty and desperation that its policies have imposed on Egyptian society.

\section{THE ALLIANCE ONLINE}

I have described a couple of key moments in the emergence of political blogging in Egypt and its import relation to opposition movements in the country. I want now to sketch out some of the features that give coherence and unity to the heterogeneous currents that make up this arena of public dialogue and citizen journalism. Activist bloggers from across a wide political spectrum are brought together online through a shared sense of what are the most pressing political challenges Egyptians must face today. Four issues have helped to define a common moral stance: 1) a forceful rejection of the Mubarak regime and a demand for its end; 2) a stand against tawrith, or "succession," specifically Gamal Mubarak's succession of his father as president of the country; 3) a demand for the expansion of political freedoms and the creation of fair and democratic institutions; and 4) a condemnation of routinized state violence. A fifth point of convergence lies in a concern with the plight of the Palestinian people and an insistence that Arab states have a responsibility to protect them. Stands on these issues are often marked on blogs with small banners, some linked to websites of associations and solidarity groups. Although those who come to this common ground do so through different institutional experiences - bringing with them different conceptions of the place of religion within politics-, they write and interact within this corner of the blogosphere as participants in a shared project. These issues, in other words, provide common ground for the forms of citation, interaction, and commentary found across both leftist and Islamist websites. 
For Islamist activists and members of the Muslim Brotherhood, this agenda marks a radical shift. Until quite recently, Islamist political arguments have focused on the importance of adopting the shari'a as a national legal framework, and on the need to counter the impact of Western cultural forms and practices in order to preserve the values of an Islamic society ${ }^{7}$. Granted, an earlier generation of intellectuals linked to Islamic political parties had since the mid 1980s emphasized the necessity of democratic political reforms. Leading Islamist writers such as Fahmi Howeidi, 'Abd al-Wahhab al-Messiri, and Tarek al-Bishri had attempted to build a movement that would bring about an end to the rampant corruption afflicting Egypt's political institutions and establish a solid basis for representative governance; but their viewpoints generally remained marginal within Islamist political currents, and the organizations they tried to establish were largely undermined by the state. For many of those making up the new generation of Islamist activists, however, the goal of creating a flourishing Islamic society must start with the reform of Egypt's stultified authoritarian system, and therefore, with the development of a political discourse capable of responding to the requirements of this task. This political reorientation can be seen in a recent statement by Ibrahim Hodeibi, an important voice among the new generation of Brotherhood members, and a well-known blogger. Writing in the context of a debate with fellow Brotherhood members about the future of the organization, Hodeibi suggests that the Brotherhood slogan, "Islam is the solution," should be replaced by the religiously-neutral "Egypt for all Egyptians". I would caution, however, against a too hasty assumption that the abandonment of religious references - a constitutive feature of the political blogosphere I am addressing here- can be taken as a symptom of the secularization of political life in Egypt ${ }^{9}$. Rather, and as many of the bloggers I spoke with in Cairo insisted to me, what is marked by this shift is a recognition of the necessity of creating a language of political agency capable of encompassing the heterogeneity of commitments — religious and otherwise-that characterize Egyptian society. Blogs, I am arguing, have provided a unique space for the elaboration of such a form of political discourse, and are enabling the creation of new models of political citizenship, including by those who are concerned with preserving the Islamic character of Egyptian society.

7 Useful analyses of the Islamist movement in Egypt are found in Baker (2003), Mahmood (2005), Salvatore (1997, 2001).

${ }^{8}$ Hodeibi's viewpoints are discussed in Lynch 2007b.

${ }^{9}$ Nor can this shift of reference be understood as the triumph of a nationalist perspective over an Islamic one. From its first inception early in the 20th century, the Muslim Brotherhood in Egypt has always incorporated a strong nationalist orientation into their social and political agendas. See Mitchell's (1993) excellent account of this movement. 


\section{SENSORY POLITICS}

In order to highlight the sensory politics undergirding this practice of activist journalism, I want to trace its overlap with and departure from a somewhat different arena of ethical and political discourse. In my earlier work, I discussed the emergence in Egypt of what I called "an Islamic counterpublic" (Hirschkind 2001, 2006). Articulated by the wide circulation of popular cassette-recorded sermons among the lower and lower-middle classes in Cairo, this public arena connects Islamic ethical traditions to practices of deliberation about the common good, the duties of Muslims in their status as national citizens, and the future of the greater Islamic community. Sermon tapes provided one of the means by which Islamic traditions of ethical discipline were accommodated to a new social, political, and technological order, to its rhythms, noise, its forms of pleasure and boredom, but also to its political incitements, its call to citizenly participation. Within this context, public speech is not geared to the formation of political policies, but rather, to the cultivation of pious dispositions, the embodied modes of expression understood to facilitate the development and practice of Islamic virtues, and therefore, of Islamic ethical comportment.

Notably, both the cassette sermon and the blog, in different ways, exploit a kind of noise in order to articulate a domain of social-moral existence that defies the normalizing discourses of the state. Recorded live at the mosque, on low tech, low-priced equipment, sermon tapes reproduce, not simply the discursive content of the sermon, but all of the surrounding noise - the horns and other street sounds, the pious (and raucous) responses of the audience, as well as all of the noise accumulated on the tape in the course of being passed along and copied from one listener to the next (Hirschkind 2006: 8-12). In their multiple layerings of electronic and urban interference, tapes disclose, make audible, a world of pious listeners, what I called "an Islamic counterpublic." Blogs also exploit the epistemic value of a certain noise, of two kinds in particular: the gritty abrasiveness of the vernacular and the fuzziness and instability of the video sound-image produced by the cell-phone.

Outside of modern literature, Colloquial Egyptian Arabic has rarely been used as a written language. Attempts to assign it the status of the authentic voice of the people have always been limited by classical Arabic's proximity to the Quran, and thus to what has remained for most Egyptian Muslims an exemplary voice, one not only central to the variety of citational and recitational practices through which one cultivates a closeness with God, but also pervasive within daily speech, as a common stock of expressions through which the most mundane actions find their ethical framing. Classical Ara- 
bic, in other words, has never become just a written form, but has always remained tied to its resonant sound, a sound essential to and formative of parts of one's most intimate voice ${ }^{10}$. Hence, within the cassette-sermon public I have written about, the ethical and rhetorical resources of classical Arabic are necessary to political action and reflection ${ }^{11}$.

The use of colloquial Arabic within the blogosphere I am describing is more or other, therefore, than just an authentic voice of the people. On the one hand, and most obviously, its distance from the writing styles of other textual media signals a judgment on the illegitimacy of Egypt's political institutions, not simply those of the state but also the organizations of political opposition which, from the standpoint of many Egyptians, have long been overcome by corruption and bureaucratic inertia. Such writing highlights its independence from the dominant discourses of Egyptian political life that circulate via print and televisual media. But recourse to written colloquial Arabic does more than simply mark a distinction. Many of the most popular blogs - those most frequently visited both by the secular-leftists and Islamists I spoke with in Cairo during 2008 - push this distinction further by deploying a particularly vulgar form of the vernacular. The fact that people affiliated with the Muslim Brotherhood or generally supportive of Islamist currents within society find such writing valuable, persuasive, insightful is striking, given the emphasis on pious modes of speech and comportment found within Islamist associations. As I mentioned, the media forms developed by Islamic reform movements in modern Egypt have foregrounded the rhetorical powers of Quranic speech to transform and improve the sensitive listener. How do we understand such a radical departure from that tradition by some members of the current generation of Islamist activists?

Take for example the comments of a blogger I spoke with named Fatima, a woman who also writes for the popular website Islamonline, and practices a more strict form of personal piety than many Egyptians (not shaking hands with men, and so on). In one conversation, Fatima mentioned to me that one of the blogs she visited most frequently was that carrying the name "Malcolm X", one of the most popular of the Egyptian political blogs and well known for its author's liberal if not excessive recourse to Egyptian vernacular's crudest expletives. Fatima said that although she often found the language excessive and disturbing, the blogger's political insights, his ability to give expression to Egypt's dire political predicament were without

${ }^{10}$ See Haeri's (1997) insightful discussion on the politics of language today in Egypt.

${ }^{11}$ On the ethical and devotional dimensions of classical Arabic see Graham (1985, 1987), Padwick (1996), Sells (1999). 
parallel and well worth putting up with the verbal assault. Even more surprising, she then told me that she frequently told him in person that he should reform his language. They had come to know each other as members of a group called "Solidarity Committee against Violations of the State", an association put together by online activists. It is the experience fashioned within the blogosphere and the resultant practices of political engagement - I want to argue - that have made possible such exchanges and forms of cooperation. This observation was not exceptional: many of the young people I spoke to who were or had been affiliated with the Brotherhood emphasized, though not without some ambivalence, their appreciation for bloggers who mined the rougher edges of street language.

These comments, I want to propose, need be understood in light of the specific use to which text and image is put within the blogosphere. As a primarily visual space, blogs leave behind the resonant word at the heart of Islamist projects of reform and instead assume the task of putting on display, objectifying state violence, as a pervasive condition of contemporary Egyptian experience. Despite its reliance on a colloquial form, the style of expression which has in some ways come to define the Egyptian political blogosphere twists away from the verbal utterance, becoming unsayable, unhinged from the languages that shape and sustain ethical community. What it loses in utterability, however, it gains as a material artifact: a disfigured social body visually registering a condition of generalized violence. It is written colloquial, in other words, that can break with its own sound and all of the ethical attachments of aurality within Islamic rhetorical traditions, and come to inhabit the visual frame of the blog as an icon of disfigurement and subordination, of collective injury ${ }^{12}$.

This fracturing of language is also a fracturing of ethics from politics, what might be described as a process of secularization, one founded on a split between two sensory modalities, eye and ear. Notably, one of the primary points of tension and conflict between Brotherhood bloggers and the older directorate has been around the issue of whether da'wa-the activity of promoting adherence to pious standards- ${ }^{13}$ can be separated from politics without undermining the Islamic quality of society-a question that many of the younger Brothers have affirmed in the positive (Lynch 2007a, 2007b; Shehata and Stacher 2006). For those making up the new generation

12 This injury is also registered graphically in some instances, through the practice of stretching out single words across the entire screen through the repetition of one of more of the word's letters.

13 On the history of da'wa in the modern Middle East, see Canard (1999), Mahmood (2005), Wardernburg (1995). 
of Islamist activists, the goal of creating a flourishing Islamic society must start with the reform of Egypt's stultified authoritarian system, and therefore, with the development of a political discourse capable of responding to the requirements of this task. To be effective today, they argue, such a discourse must be disencumbered from the pedagogical project of ethical reform that has been central to Islamist political thought and practice. The blogosphere I have been describing contributes to this project, less in terms of the development of a political discourse than as a site wherein political affects are solicited and honed, where the experience of a violated national subject is objectified and cultivated.

The cell-phone videos that circulate widely within the Egyptian blogosphere also accord with and enhance the perceptual habits I have been describing. Many of the videos record encounters between state security forces and demonstrators. The fleeting, unsteady, often unfocused images testify to a surreptitious eye, threatened, evasive, bearing witness again and again to acts of state repression. The sounds heard are a blend of automobile noises, voices from the crowd, stray expressions of fear, amazement, and outrage from those filming. Beyond documenting specific acts of criminality by state security forces - an extremely important function - these films, in their endless variety and extensive proliferation, create a vast tableau of a society under siege —or what bloggers simply call the "street".

\section{PROTOCOLS OF DISCOURSE}

Interestingly, the protocols and practices of interaction in the blogosphere are not always recognized outside it. For example, when I spoke to secularist bloggers, many tended at first to dismiss the idea that they would have anything to do with Islamists; that on Islamist sites you would only find things like calls to kill impious actors and writers. When I pointed out that their own sites included many links to sites of people self-identified as Muslim Brothers, and that in their own online writings they commented positively on the participation of Islamist activists in organizing demonstrations and building public awareness of pressing political concerns, then they would begin to note exceptions. In other words, the kinds of statements and interactions within the blogosphere crosscut divisions, divisions that still remain marked —in speech and associational life- outside it. While they recognize the difference between their political commitments and those of other bloggers, they engage with an orientation toward creating conditions of political action and change, and therefore seek to develop arguments, styles of writing and self-presentation that can bridge these differences and hold the 
plurality together. As one secularist blogger put it in commenting on the protocols of online engagement: "The atheists reign in their contempt for religion, while the religious bloggers - who would not even accept the existence of non-believers in the first place-can now see some shared values."

This also means that online participants frequently end up engaging with topics, arguments, and people they would not tend to encounter offline. A Christian blogger I spoke with and who contributes to this arena used the example of gay Egyptian activists, noting that while many of the bloggers would be uncomfortable associating with people who they knew to be gay in real life, because of the interactions of self-identified gay bloggers in the blogosphere many online participants — both Islamist and secularist - had come to recognize a common ground with them, and to value their contributions to a shared critical project. Once a topic acquires a momentum in the blogosphere, even those who might otherwise avoid it are led to engage it openly as a condition of sustaining the arena of discourse they have collectively forged and remain committed to. Islamist contributors to this project now have to address topics like sexual harassment —an issue that would rarely be raised in Egypt, but even more rarely in Islamist circlesand to think about them publicly in a style that acknowledges the heterogeneity of viewpoints among their readers. Insomuch as bloggers, both secular and Islamist, position themselves within this arena of activism and discourse, they necessarily address this question and others, including problems of religious minorities (copts, bahais and shi'a) and issues of freedom of expression and freedom of religion.

The style of reasoning characteristic of this blogosphere foregrounds a language of individual self-reflectivity and critical engagement while eschewing what is understood to be its opposite: denunciation and dogmatism. In this, it follows a trend long ago recognized by scholars of contemporary Islam (Eickelman 1992, Eickelman and Anderson 1999). As with the practice of blogging in much of the world, this commitment to individual reasoning is marked rhetorically by an insistence that one is speaking outside of all institutional affiliations and strictly for oneself. Bloggers exploit the blog format, particularly the personal profile page, in order to fashion an online persona that transcends the stereotypes that function to limit political argument. Thus, the blogspot protocol of providing a personal description, replete with favorite films, books, and blogs is used to create and sustain less a unique individuality than a sense that one is an "ordinary Egyptian," not a Muslim Brother, not a Coptic Christian, not a communist, but someone with the likes and dislikes of other Egyptians. Thus, one's self-declared identity as a member of Ikhwan (the Muslim Brotherhood) does not exhaustively define one's social, political, and religious identity, as other aspects of self are highlighted, 
displayed. This has allowed for the possibility of linkages, the articulation of shared interests and desires that otherwise would remain hidden, or at least fail to find institutional expression within existing forms of affiliation and political action. According to the most prominent Brotherhood blogger, 'Abd al-Mun'im Mahmud, this particular form of self display has helped to "humanize" Brotherhood Members, to show the extent to which they share tastes and desires of other Egyptians, and in so doing, has opened up possibilities of mutual recognition and alliance foreclosed by reigning stereotypes. Mahmud's own site is called Ana Ikhwan, "I am the Brotherhood," a title that calls to be read ironically as "I am the Brotherhood, and yet...I am just like you" 14 .

The rhetoric of individual self-expression and reasoning - I say "rhetoric" not to suggest it is a false claim but to keep in mind that it is intimately a collective political project that orients the discourse, not simply the desire for self-expression - this rhetoric goes hand in hand with an openness to engage with a global political culture. One sees this openness quite dramatically on websites like Islamonline, a site that a number of Islamist bloggers write for when not tending their blogs. While space does not permit me to go into the importance of this site in relation to shifting practices of dialogue and news reporting, I will briefly draw a couple of examples, based on conversations I had with Islamonline writers during 2008.

First, I would note that Islamonline - a site dedicated to promoting a correct understanding of Islam and which addresses issues understood to be of relevance to Muslims - frequently hires non-Muslims to work for them. As a journalist writing for the web site explained to me, "we don't see any problem having non-Muslims write for us, as long as they are not addressing religious issues." A second and striking example of the openness and lack of dogmatism on this site can be seen in their decision to hold a live open forum with and about Muslim gay activists in the US a couple of years ago. No other media agency in Egypt — secular or religious- would host such an event. Note as well that Islamonline published a review of The Jewel of Medina, a book about the prophet's wife Aisha that many consider to be one more example of Islam-bashing disguised as literature. The reviewer did indeed find great fault with the book on both historical and aesthetic grounds, but, against many other voices, argued that it was better to engage with such books openly and critically instead of through censorship. This view, that one must remain open to what is taking place in the world, marks a significant change from the defensive posture taken by an earlier generation in regard to Western media and culture. This is not to say that this gener-

${ }^{14} \mathrm{http}: / /$ ana-ikhwan.blogspot.com/ 
ation of Islamist activists and bloggers are simply adopting Western cultural models (many of the Islamonline writers I met, as I mentioned, insisted on strict observance of a variety of religious duties). Rather, it points to the way secularization is no longer the primary enemy in the way it had been, a stance evident in a far less defensive posture by young Islamist writers ${ }^{15}$.

This attitude of critical engagement among bloggers from the Muslim Brotherhood has met considerable resistance from the older generation of Brothers that continues to dominate the organization. Many younger Brotherhood members have turned to the blogosphere to elaborate a serious and sustained critique of the old guard and its policies-and have in return been severely criticized by the old guard, who forced some to shut down their sites ${ }^{16}$. It is particularly the willingness of the young bloggers to discuss openly and publicly questions regarding the governance and direction of the organization that the older generation finds unacceptable.

\section{CONCLUSION}

As I noted above, one aspect of my earlier work in Egypt concerned the emergence of what I called "an Islamic Counterpublic", one for which the cassette recorded sermons and other religious oratory play an important constitutive role. The political blogosphere I have been describing departs from this Islamic counterpublic in some key aspects. Most notably, the web-based arena is predicated on a separation of da'wa - the activity of promoting adherence to pious standards - from politics. This separation is evident in the shift from a discourse imbued with the performative and poetic resources of the Quran and other Islamic ethical genres to one centered on the concepts of a modern democratic political order (a shift further emphasized by the extensive use of vernacular on blogs). Indeed, one of the points of tension and conflict between Brotherhood bloggers and the older directorate has been around the issue of whether da'wa can be separated from politics without undermining the Islamic quality of society — a question that many of the younger Brothers have affirmed in the positive.

There are also, however, ways in which the practice of blogging has built on and extended certain trends developed in the sermon public I described. An obvious overlap, of course, is found in the emphasis on deliberation and contestation as necessary to the reform of Egyptian social and political life.

15 The Islamist thinker and public intellectual Fahmi Howeidi echoed this point in conversation we had on the topic.

${ }^{16}$ See Lynch (2007a) for an insightful discussion of these tensions within the Muslim Brotherhood. 
There is also a similarity, however, in the way the conditions of production of the two media forms - the cassette sermon and the blog- facilitate the articulation of a domain of social-moral existence that defies the normalizing discourses of the state. As I noted above, both give expression to a space of violence, violence with an impact that is registered on both speech and vision (e.g. the trembling and surreptitious eye of the cell phone video). They also both construct a new kind of agency within this domain, in the case of the blogs, an agency conceived in explicitly political terms.

Lastly, both the counterpublic and the blogosphere share a concern for social discipline, what in the da'wa arena is often called tabthib - the polishing of one's ethical capacities - and what most of the bloggers I spoke with referred to as tathqif - from the word thaqafa, meaning "culture," but here deployed to suggest a process of inculcating skills of political judgment, reasoning, and argument. As 'Abd al-Mun'im Mahmud told me: "our aim is not to build a political party or bring about a revolutionary overthrow of the government. Our goal in blogging, rather, is to bring about political consciousness, to create a culture of informed engagement, a willingness to challenge and critique the state." This goal is to be brought about not by the embodied disciplines of da'wa, though it does involve the development of the attitudes and dispositions that make dialogue and critique between Muslims and Christians, between Islamists and secularists, within the blogosphere possible. In this sense, it necessitates the fashioning of a set of political virtues that, while not Islamic in and of themselves, are understood, at least by Islamist bloggers, as necessary to creating the political conditions within which an Islamic society might flourish.

\section{REFERENCES CITED}

Abdo, G. 2000. No God but God: Egypt and the Triumph of Islam. New York: Oxford University Press.

Agrama, H. 2010. "Ethics, Tradition, Authority: Toward an Anthropology of the Fatwa." American Ethnologist 37 (1): 2-18.

Baker, R. 2003. Islam without Fear: Egypt and the New Islamists. Cambridge: Harvard University Press.

Beinin, J. and J. Stork. 1997. "On the Modernity, Historical Specificity, and International Context of Political Islam", in J. Beinin and J. Stork (eds.), Political Islam: Essays from Middle East Report: 3-32. Berkeley and Los Angeles: University of California Press.

Bunt, G. 2009. iMuslims: Rewiring the House of Islam. Raleigh: University of North Carolina Press.

Canard, M. 1999. "Da'wa", in The Encyclopedia of Islam. CD-ROM, version 1.0. Leiden: Brill.

Eickelman, D. 1992. "Mass Higher Education and the Religious Imagination in Contemporary Arab Societies". American Ethnologist 19 (4): 643-655.

Eickelman, D. and J. Anderson (eds.). 1999. New Media in the Muslim World: The Emerging Public Sphere. Bloomington: Indiana University Press. 
Faris, D. 2009. "The End of the Beginning: The Failure of April $6^{\text {th }}$ and the Future of Electronic Activism in Egypt". Arab Media and Society 9 (Fall). (http://www.arabmedia society.com/?article $=723$ )

Graham, W. A. 1985. "Quran as Spoken Word: An Islamic Contribution to the Understanding of Scripture”, in R. C. Martin (ed.), Approaches to Islam in Religious Studies: 2340. Tucson: University of Arizona Press.

Graham, W.A. 1987. Beyond the Written Word: Oral Aspects of Scripture in the History of Religion. Cambridge: Cambridge University Press.

Haeri, N. 1997. "The Reproduction of Symbolic Capital: Language, State, and Class in Egypt". Current Anthropology 38 (5): 795-806.

Hirschkind, C. 2001. "Religious Reason and Civic Virtue: An Islamic Counter-Public". Cultural Anthropology 16 (1): 3-34.

Hirschkind, C. 2006. The Ethical Soundscape: Cassette Sermons and Islamic Counterpublics. New York: Columbia University Press.

Lynch, M. 2007a. "Young Brothers in Cyberspace". Middle East Report 245 (Winter). (http://www.merip.org/mer/mer245/lynch.html)

Lynch, M. 2007b. "Blogging the New Arab Public". Arab Media and Society 1. (http:// www.arabmediasociety.com/?article=10)

Mahmood, S. 2005. Politics of Piety: The Islamic Revival and the Feminist Subject. Princeton: Princeton University Press.

Mitchell, R. 1993. The Society of the Muslim Brothers. Oxford: Oxford University Press.

Norton, A. 2005. "Thwarted Politics: The Case of Egypt's Hizb al-Wasat", in R. Hefner (ed.), Remaking Muslim Publics: Pluralism, Contestation, Democratization: 133-160. Princeton: Princeton University Press.

Padwick, C. 1996. Muslim Devotions: A Study of Prayer-Manuals in Common Use. Oxford: Oneworld Publications.

Radsch, C. 2008. "Core to Commonplace: The evolution of Egypt's Blogosphere". Arab Media and Society 6. (http://www.arabmediasociety.com/?article=692)

Salvatore, A. 1997. Islam and the Political Discourse of Modernity. Berkshire, England: Ithaca Press.

Salvatore, A. 2001. "After the State: Islamic Reform and the 'Implosion' of Shari'a", in A. Salvatore (ed.), Muslim Traditions and Modern Techniques of Power: 123-140. Münster (Germany): LIT.

Sells, M. 1999. Approaching the Qur'an: The Early Revelations. Ashland, Ore.: White Cloud Press.

Shehata, S. and J. Stacher. 2006. "The Brotherhood Goes to Parliament". Middle East Report 240 (Fall). (http://www.merip.org/mer/mer240/shehata_stacher.html)

Skovgaard-Petersen, J. 1997. Defining Islam for the Egyptian State: Muftis and Fatwas of the Dar al-Ifta'. Leiden: Brill.

Stacher, J. 2002. "Post-Islamist Rumblings in Egypt: The Emergence of the Wasat Party". Middle East Journal 56 (3): 415-432.

Waardenburg, J. 1995. "The Da'wa of Islamic Movements", in Actas, XVIe Congrès Union Europeenne d'arabisants et d'islamisants: 539-549. Salamanca, AECI/CSIC/UEAI.

Wickham, C. R. 2004. "The Path to Moderation: Strategy and Learning in the Formation of Egypt's Wasat Party". Comparative Politics 36 (2): 205-228.

Fecha de recepción: 1 de marzo de 2010

Fecha de aceptación: 23 de marzo de 2010 